\title{
Are Insurgents any Different from Counterinsurgents? A Systematic Integration and Validation of Motivational Studies from Colombia
}

\author{
Enzo Nussio, Universidad de los Andes (Bogotá) \\ Juan E. Ugarriza, Universidad del Rosario (Bogotá) ${ }^{1}$
}

\begin{abstract}
Are combatants from insurgent and counterinsurgent groups the same people? Evidence suggests that they go through different war experiences and socialization processes and may also behave differently after demobilization. In this study, we demonstrate that members of guerrilla and paramilitary groups in Colombia were already driven by clearly distinguishable motivations in their decision to join the respective groups, beyond contextual constraints. This implies that the insurgent-counterinsurgent cleavage does not only stem from macro-level conditions, but is also situated in the minds of potential recruits since before they join. Our analysis is based on a systematic integration of relevant hypotheses extracted from earlier studies and a validation of their findings with a survey database of 1,485 ex-combatants in Colombia.
\end{abstract}

Key words: insurgency, counterinsurgency, conflict, war motivations, Colombia, research synthesis, validation

\footnotetext{
${ }^{1}$ We are very grateful to the Fundación Ideas para la Paz for generously sharing their data of a nationwide survey of ex-combatants in Colombia. We thank Natalia Gutiérrez and Usdin Martínez for their research assistance. Also, we would like to thank Erin McFee, Ben Oppenheim, Jacob N. Shapiro, Michael Weintraub, and participants at a panel during the ISA Annual Convention 2013 in San Francisco for their comments. Enzo Nussio's participation in this project was financed by a prospective researcher fellowship of the Swiss National Science Foundation.
} 


\section{Introduction}

Many internal conflicts share the following characteristics: government forces fight insurgents, and irregular counterinsurgent groups, pro-government militias, or paramilitaries then attack insurgents back. Those who join the counterinsurgent and insurgent groups are usually young, poor men. Could we even say that they are basically the same people, despite the many local nuances that complexify each instance of internal conflict?

While existing works hint at important considerations of cleavages, tactical variance, and network formation (Beckett 2001; Berger and Borer 2009; Joes 2006), due to methodological constraints side-by-side case study comparisons can only suggest rather than prove a comprehensive accounting of the contrasts between insurgents and counterinsurgents. These descriptions also tend to be confined to macro and meso levels, in which differentiation factors are analyzed in terms of war dynamics and group strategies in countries like Zimbabwe, El Salvador, Peru and Iraq (Kesby 1996; KocMenard 2007; Lungo Uclés 1996; Pampinella 2012). There are few studies in which a micro-level comparison between members of rival illegal factions has been undertaken. Mason (1996), for example, takes a formal model approach to attempt generalizable conclusions, while Humphreys and Weinstein (2008) offer a context-embedded analysis of Sierra Leone's former members of antagonistic armed groups. Interestingly enough, micro-level comparisons are most abundant for the Colombian case. Here, previous literature suggests that there are differences in guerrillas versus paramilitaries demographics (Gutiérrez Sanín 2008), motivations for joining (Arjona and Kalyvas 2011), socialization processes within their groups (Ugarriza and Craig 2013), reasons and modalities for demobilizing (Villegas 2009) and post-conflict reintegration processes (Ribetti 2009). 
However, while all the studies mentioned above make important contributions to the question of insurgent versus counterinsurgent differences, the complexities of investigating and generalizing findings around this topic confound methodological and theoretical attempts to provide a comprehensive understanding. Most of the studies rely on interviews and surveys with former combatants. Data on this individual level of analysis is affected by systematic bias, selection problems, retrospective story-telling and blunt lying (see Kalyvas 2006, 100). A potential way out of these seemingly insurmountable obstacles for empirical research is a wider integration of methods and theories.

We therefore propose a systematic synthesis of findings from earlier studies by first extracting their relevant hypotheses and second validating them externally with a Reference Database (see below): The relevant selected hypotheses are contained within a single national context, since each conflict context and recruitment strategies of nonstate armed groups in different countries are difficult to generalize. Here, we will cull our hypotheses from existing studies based on the Colombian case. This case provides several advantages: First, Colombia is a case with a long-term presence of antagonistic illegal non-state armed groups. Second, our integrative approach finds fertile soil in Colombia since we can build on ten studies that directly address our research question drawing from different theoretical strands and leveraged different methods of investigation. Five of them deal specifically with factors that differentiate insurgents from counterinsurgents, and the remainder address reasons for joining either one of the sides. All ten studies are used to define a list of hypotheses that have found prior empirical support. We have chosen to focus on hypotheses about motivations, rather than on organizational socialization processes, war experiences and demobilization and reintegration dynamics because we are interested in the mindset of would-be recruits 
before they engage in one or the other group. The other mentioned sources of differentiation are related to group dynamics and shared experiences that not surprisingly shape differences across groups.

After extracting relevant hypotheses, we conduct a logit confirmatory analysis for factors that can be attributed to pre-enlistment conditions, in order to select the most robust ones. For this procedure, we use a Reference Database that consists of randomly sampled data from a survey of 1,485 former paramilitaries and insurgents. This database has several advantages over existing data, while it shares some of their limitations and problems. The sample is close to representative of the population of demobilized combatants participating in the reintegration program in 2008 (about 30,000 excombatants). Also, the survey asked about a series of issues related to the excombatants' pre-war, during war and post-war experiences and attitudes, covering a range of topics unprecedented in previous data collection efforts. This broad inclusion of relevant themes allows for testing a wide range of theories.

We conclude with our results and a discussion of whether pre-recruitment conditions determine the difference between insurgents and counterinsurgents, or whether the recruitment strategies of each group and experiences during their participation in the group offer a more plausible explanation for encountered differences. Our novel integrative approach and successive findings advance the reliability, validity, and comprehensiveness of our understanding of individual differences between insurgents and counterinsurgents in conflict settings, and help to resolve disparate findings in existing literature.

In the Colombian case, the two most important guerrilla groups in the early $21^{\text {st }}$ century are the Revolutionary Armed Forces of Colombia (FARC) and the National Liberation Army (ELN). Both are communist insurgencies and were founded in the 
early 1960s (see Pizarro Leongómez 2011; Medina 1996). While the FARC has been the main threat to national security-especially during the late 1990s and the early 2000s when they controlled extensive areas of the Colombian territory, the ELN has been less important militarily, but still dominant in certain stronghold regions. Although several smaller guerrilla groups demobilized in the first half of the 1990s (among them a dissident group of the ELN), both the FARC and the ELN have experienced frustrated negotiation attempts with national governments. Since the 1980s, the government has offered benefits to guerrilla members who desert from their organization. This policy was strategically emphasized and provided with large resources between 2002 and 2010, when about 20,000 guerrilla combatants individually demobilized. According to estimates by the Colombian Armed Forces in 2012, the FARC still had about 8,000 and the ELN about 2,000 members in arms.

Paramilitary groups were the other major illegal armed actors in the history of the Colombian conflict. They emerged largely in the 1980s in several rural areas as a reaction to the increasing dominance of guerrilla groups. The formation of these groups has been related to large landowners and drug-traffickers since its beginnings, and parts of the government and the military have collaborated with paramilitary groups or at least tolerated them at various times (Romero 2003). It is a matter of debate if these paramilitary groups were pure counterinsurgents, local warlords (Duncan 2006), or disguised drug-traffickers (Cubides 2005). However, they were an important antagonist of guerrilla groups in the Colombian conflict and we thus label them as counterinsurgents for our research purposes. ${ }^{2}$ In 1997, an effort to convert the regionally fragmented paramilitary groups into a national organization led to the creation of an umbrella organization called United Self-Defense Forces of Colombia (AUC). The

\footnotetext{
${ }^{2}$ In the remainder of this paper, we use the terms paramilitary and counterinsurgency, as well as guerrilla and insurgency interchangeably.
} 
AUC were the main group responsible for massacres and other crimes against humanity in the years following (CNMH 2013). After negotiations with the government, the AUC demobilized their armed structures between 2003 and 2006 (Nussio 2011a). Criminal groups, sometimes referred to as neoparamilitaries, have inherited some of their “businesses,” especially the drug trade (see Granada, Restrepo, and Tobón 2009).

\section{Reasons for joining non-state armed groups}

As stated in the introduction, research about the wider question of reasons for joining non-state armed groups is extremely challenging. Not surprisingly, a series of diverse empirical strategies relying on different types of evidence have been employed to counterbalance its inherent difficulties (for an extended overview, see Blattman and Miguel 2010, 32-35).

Most recent studies by political scientists and economists have employed aggregate level data to uncover reasons for joining. Collier and Hoeffler (1998; 2004), Fearon and Laitin (2003) and more recently Boix (2008) are examples of scholars who have used cross-country data, much like in the wider causes of conflict literature, to infer motivations of armed groups and individuals. A series of studies on subnational entities has followed the cross-country studies - their dependent variables mostly represent conflict activity or insurgent violence (see for example Berman et al. 2011; Dube and Vargas 2008; Regan and Norton 2005; Vadlamannati 2011). However, inferences from aggregate level data to individual behavior are problematic. Several rival theories for individual action may be consistent with findings on the aggregate level. Also, this literature tends to identify somewhat static and homogeneous motivational theories for entire armed groups. Nevertheless, these studies have made 
important contributions to the understanding of opportunity structures for participation in armed groups.

Another branch of studies has based their empirical analysis on individual level data. Recently, surveys comparing combatants with non-combatants (Humphreys and Weinstein 2008) and comparing combatants across different armed groups-insurgents versus counterinsurgents (Arjona and Kalyvas 2011)—have been conducted. By using ex-combatants as respondents, they are effective in unveiling variation across individuals and testing some of the theories developed on aggregate levels of analysis with more fine-grained data. However, they suffer from the same problems as does any retrospective survey (see below section on Empirical Data): reasons for joining might shift in retrospective narrative accounts, respondents might have incentives to lie to make their past actions look better, only survivors are selected for the surveys, which leads to systematic error, and complex decision processes can hardly be accounted for with mostly closed-ended survey questions (see Blattman and Miguel 2010; White 2007). Some of these difficulties can be overcome by qualitative and mixed research strategies, which have been employed in recent research on participation in war (see for example Bosi 2012; Jonsson Forthcoming; Kalyvas and Kocher 2007; Theidon 2007; Wood 2003). However, just like in survey studies, they run the risk of imputing at face value desires as articulated by interviewees.

We take a broader approach to war motivations than existing studies, increasing the robustness of previous findings by systematically integrating and validating prior theories about factors differentiating insurgents' reasons for joining non-state armed groups from those of counterinsurgents. 


\section{a) Theories about joining armed groups}

In order to allow for a systematic integration of the Colombian contributions into the wider literature of reasons for joining non-state armed groups ${ }^{3}$, we identify at least five distinctive sets of theories related each one to one central "background concept" (Adcock and Collier 2001): grievances, selective incentives, networks, private desires and coercion. ${ }^{5}$ Since our typology is based on sometimes contradictory theories with overlapping boundaries, the following categories cannot be mutually exclusive (Collier, LaPorte, and Seawright 2012). Rather, similar theories are grouped into the same category which may result in somewhat blurry categories, corresponding to a family resemblance understanding (Collier and Mahon 1993; Wittgenstein 2003). It is important to be cautious about the individual contribution of each theory to the understanding of reasons for joining armed groups, since "both joining a rebel army and collaboration with it result from variable and complex sets of heterogeneous and interacting motivations" (Kalyvas 2006, 95).

Grievances: Theories formed around the concept of grievance have been most salient in the early literature on social revolution and guerrilla movements (see for example Davies 1962; Gurr 1970; Paige 1975; Scott 1976; Wickham-Crowley 1992), not on counterinsurgents. The common supposition of these theories is that members of certain social groups (typically poor urban classes, landless peasants or ethnic minority groups) who feel mainly economically, but also socially and politically disadvantaged may be discontent and develop frustration to the point that they seek violent means of change. Relative deprivation (the mismatch between expectations and actual achievement) is the fundamental mechanism driving decision-making for the above

\footnotetext{
${ }^{3}$ The wider literature does often not distinguish between theories about insurgencies and pro-government militias.

${ }_{5}^{4}$ Systematized concepts and indicators will be introduced in the subsequent sections.

${ }^{5}$ For alternative overviews, see Blattman and Miguel (2010), Humphreys and Weinstein (2008), Justino (2009), Kalyvas (2006, especially 95-104), Ohlson (2008).
} 
cited grievance theorists. Most proponents of this theory focus on the opportunity dimension of their argument: the social and economic position determines participation in revolutions and armed groups.

Selective incentives: Another set of theories is based on rationalist accounts of individual behavior and the related collective action problem (Olson 1965). According to the collective action problem, it is irrational to voluntarily participate in such a risky enterprise as an insurgency with the aim of achieving some public good. The logically following question is why someone would choose to rebel as opposed to free-ride. Some authors propose selective incentives as a way out of the collective action problem (Lichbach 1995). Selective incentives include mostly economic incentives like money, the opportunity to loot, or access to land, as stated by greed theorists (Collier and Hoeffler 1998; Collier and Hoeffler 2004; see also Grossman 2002; Keen 2000; Weinstein 2007). Humphreys and Weinstein $(2008,441)$ call the mentioned economic incentives "pull factors". However, selective incentives might also push people into armed groups. Kalyvas and Kocher (2007; see also Goodwin 2001), for instance, argue that in a civil war context, it might be safer to be in a group than outside of it. These pull and push selective incentives are relevant for both insurgent and counterinsurgent groups (Kalyvas 2006, 95-98).

Networks: The collective action problem might also be overcome by strong community ties, primary group cohesion, peer pressure, and social sanctions (Kalyvas 2006; Petersen 2001; Scott 1976; Taylor 1988). Although this argument can be linked to the addressing of the collective action problem, it could also be recast as a necessary condition for participation in armed groups: Without networks and contacts within armed groups, there are no opportunities to become involved with them. Here we see one instance in which the boundaries between these strands of theories are blurred, in 
that opportunity plays an important mechanistic role both for individuals who may join to address articulated grievances and those who may join because they had the socially situated opportunity to do so. An intimately local perspective on armed group participation is key to the understanding of this mechanism (Kalyvas 2003). The social networks are often family-based (Hart 1999; Roldán 2002; for many more examples, see Kalyvas 2006,95 ) and a gradual slipping into the group might be as common as a conscious decision of joining (Horton 1999). In the context of Sierra Leone, for example, community strength is found to be more important for the community defending counterinsurgent groups than for insurgencies (Humphreys and Weinstein 2008, 450).

Private desires: Several ethnographic studies have encountered another type of reasons for joining, such as the expected adventure and excitement that an armed life implies, the possibility for revenge against previous aggressors, and the reputation, status and lifestyle that result from carrying a gun and from membership in an important armed group (Tezcür 2010; Theidon 2009; Villegas 2009; for additional examples, see Kalyvas 2006, 96-7). Wood (2003) proposes a similar set of ideas in response to the "insurgent collective action problem." She identifies emotional and moral motives related to the pleasure of agency as reasons for joining. Not surprisingly, a common assumption in this theory is that the reasons for joining are encountered in the identitybased micro-world of each individual. From a rationalist perspective, such sentiments may be seen as "goods of inherent value that individuals consume by fighting" (Blattman and Miguel 2010, 15). Theoretically, both insurgent and counterinsurgent groups can provide the necessary environment to act out these desires.

Coercion: A final set of theories states that armed groups use forcible recruitment to resolve the collective action problem (Blattman and Annan 2010; Gates 2002; 
Humphreys and Weinstein 2008). Depending on different contexts, this strategy has been employed by both insurgent and counterinsurgent groups (Kalyvas 2006, 96, 98).

\section{b) Differentiating insurgents and counterinsurgents: an integrative approach}

Our attempt at knowledge accumulation in the field of differentiating insurgents from counterinsurgents is based on a series of studies conducted for the Colombian case. The presence of both insurgent and counterinsurgent non-state armed groups in Colombia over an extended period of time has attracted a lot of scholarly attention. We have identified ten studies that deal with the question of reasons for joining. ${ }^{6}$ We draw from this wealth of research a set of hypotheses and identify which of the five strands of theories mentioned above are relevant to each (Table 1); the analysis reveals that all five strands are accounted for across the ten studies.

\section{Table 1: Colombian studies about reasons for joining armed groups}

\begin{tabular}{|c|c|c|c|c|c|c|}
\hline Authors & Grievance & $\begin{array}{l}\text { Selective } \\
\text { Incentives }\end{array}$ & Networks & Coercion & $\begin{array}{l}\text { Private } \\
\text { desires }\end{array}$ & Type of evidence \\
\hline $\begin{array}{l}\text { Arjona and Kalyvas } \\
\text { (2009) }\end{array}$ & $\mathrm{x}$ & $\mathrm{x}$ & $\mathrm{x}$ & & & Survey $(\mathrm{N}=732)$ \\
\hline Gutierrez (2008) & & $\mathrm{x}$ & & $\mathrm{x}$ & $\mathrm{x}$ & Mixed data \\
\hline Villegas (2010) & $\mathrm{x}$ & $\mathrm{x}$ & & & $\mathrm{x}$ & Survey $(\mathrm{N}=682)$ \\
\hline DNP (2010) & $\mathrm{x}$ & $\mathrm{x}$ & $\mathrm{x}$ & $\mathrm{x}$ & $\mathrm{x}$ & $\begin{array}{c}\text { Survey } \\
(\mathrm{N}=1878)\end{array}$ \\
\hline $\begin{array}{l}\text { Theidon and } \\
\text { Betancourt (2006) }\end{array}$ & $\mathrm{x}$ & $\mathrm{x}$ & $\mathrm{x}$ & $\mathrm{x}$ & & $\begin{array}{c}\text { Survey }(\mathrm{N}=112) \\
\text { and interviews }\end{array}$ \\
\hline Ribetti (2007) & $\mathrm{x}$ & $\mathrm{x}$ & & & $\mathrm{x}$ & $\begin{array}{l}\text { Interviews } \\
(\mathrm{N}=15)\end{array}$ \\
\hline $\begin{array}{l}\text { Florez-Morris } \\
(2007)\end{array}$ & $\mathrm{x}$ & & $\mathrm{x}$ & $\mathrm{x}$ & & $\begin{array}{l}\text { Interviews } \\
(\mathrm{N}=42)\end{array}$ \\
\hline Jonsson (2012) & $\mathrm{x}$ & $\mathrm{x}$ & $\mathrm{x}$ & $\mathrm{x}$ & $\mathrm{x}$ & Mixed data \\
\hline $\begin{array}{l}\text { Pinto, Vergara and } \\
\text { Lahuerta (2002) }\end{array}$ & & $\mathrm{x}$ & & $\mathrm{x}$ & $\mathrm{x}$ & Survey $(N=316)$ \\
\hline Nussio (2012) & $\mathrm{x}$ & $\mathrm{x}$ & & $\mathrm{x}$ & $\mathrm{x}$ & $\begin{array}{l}\text { Interviews } \\
(\mathrm{N}=62)\end{array}$ \\
\hline
\end{tabular}

\footnotetext{
6 We exclude wider literature on insurgencies (Ferro and Uribe 2002; Medina 2008; Medina 1996; Pizarro Leongómez 2011) and the paramilitaries (Duncan 2006; Romero 2003) with an organizational focus and where cursory individual-level analysis is based on anecdotal evidence. Also, we exclude a study that focuses only on female guerrilla members (Moreno, Carmona, and Tobón 2010).
} 
Among the ten studies, we identified five in which the authors compared-either by qualitative or quantitative means_-guerrillas' and paramilitaries' motivations for joining their respective groups. ${ }^{7}$ Results from these studies provide the primary set of hypotheses for our validation analysis. We then leverage a set of five studies comprising only would-be guerrillas or paramilitaries to identify potentially relevant reasons for joining armed groups. ${ }^{8}$

\section{c) Synthesized hypotheses}

We have reformulated all of the findings of the above-mentioned studies into testable hypotheses according to the main theories of reasons for joining (additional sociodemographic characteristics will be included in the analysis as control variables). Interestingly, while some of the encountered hypotheses are almost identical, others stand in clear contradiction to one another. Hence, replication tests will unify and resolve existing findings, allowing us to move towards a more unified understanding of why individuals may join insurgent or counterinsurgent groups. Hypotheses are stated at the level of systematized concepts (and grouped according to the background concepts identified above; indicators for each hypothesis can be found in the Appendix), in order to enhance the comparability of indicators used in the original study and those to be used in this paper:

\section{Grievances:}

Hypothesis $_{1.1}$ : Ex-paramilitary respondents should more frequently cite material needs as reasons for joining armed groups, than ex-guerrilla respondents.

Hypothesis $_{1.2}$ : Ex-guerrilla respondents should more frequently cite ideological reasons for joining armed groups, than ex-paramilitary respondents.

\footnotetext{
${ }^{7}$ Arjona and Kalyvas (2009; see also Arjona and Kalyvas 2011), Gutiérrez (2008), Villegas (2009), National Planning Department - DNP (2010), Theidon and Betancourt (2006).

${ }^{8}$ Ribetti (2007), Florez-Morris (2007), Jonsson (Forthcoming), Pinto, Vergara and Lahuerta (2002), Nussio (2012).
} 


\section{Selective incentives:}

Hypothesis $_{2.1}$ : Ex-paramilitary respondents should more frequently cite material incentives ${ }^{9}$ as reasons for joining armed groups, than ex-guerrilla respondents.

Hypothesis $_{2.2}$ : Ex-guerrilla respondents should more frequently cite security issues as reasons for joining armed groups, than ex-paramilitary respondents.

\section{Networks:}

Hypothesis $_{3.1 \mathrm{a}}$ : Ex-paramilitary respondents should report to have lived in AUC-influenced areas in a higher frequency than ex-guerrilla respondents.

Hypothesis $_{3.1 \mathrm{~b}}$ : Ex-guerrilla respondents should report to have lived in guerrilla-influenced areas in a higher frequency than ex-paramilitary respondents.

Hypothesis $_{3.2}$ : Ex-guerrillas should cite more frequently their family ties with other combatants as a motivation to join their armed group than ex-paramilitaries.

\section{Private desires:}

Hypothesis $_{4.1}$ : Both ex-paramilitary and ex-guerrilla respondents should equally report retaliation as a reason to join armed groups.

Hypothesis $_{4.2}$ : Ex-paramilitary and ex-guerrilla respondents should respond differently to questions about entry-motivations related to allure for weapons/adventure.

\section{Coercion:}

Hypothesis $_{5}$ : Ex-guerrilla respondents should report more frequently forced recruitment than ex-paramilitary.

\section{Empirical data}

We will use a Reference Database (RD) in order to conduct the validation analysis of the mentioned hypotheses. This database was built on 1,485 surveys applied to former guerrillas and paramilitaries between February 5, 2008 and May 31, 2008, under the auspices of the Fundación Ideas para la Paz (FIP). While its major strength is the random selection of the sample, in comparison with other surveys applied to the excombatant population, a number of methodological limitations are also noteworthy, which we discuss further below.

\footnotetext{
${ }^{9}$ By material incentives, we mean any offerings of a material nature as a benefit for recruitment (salary, land etc.), while material needs (mentioned in hypothesis 1.1) refer to the lack of some essential need before recruitment (like adequate housing, food etc.).
} 
Out of 55,307 demobilized ex-combatants between August 2002 and December 2012, only 32,849 were actively participating in the reintegration program at the end of 2012. ${ }^{10}$ Some of those not participating were deceased, migrated, had been imprisoned, or simply decided to not join the program and thus remained anonymous (Nussio 2011b). As a result, the RD sampling drew randomly only from those actively reintegrating participants, which in 2008 amounted to 31,585 people. As such, this may not be representative of the entire population of 48,365 individuals who originally laid down their arms between 2002 and August 2008.

There is an additional challenge with identification that is a persistent concern in nearly all contexts hosting ex-combatants: an undetermined number of participants in the official demobilization process might have never actually been part of the armed groups. The degree of difficulty this challenge poses is directly in line with the State's capacity to filter impostors. It has been argued that Colombia's reintegration program is far from immune to this practice, but comparatively better equipped to prevent fraudulent claims than are some others (Nussio 2011a).

While the sample is almost representative of the population of reintegrating excombatants, the sample is not representative of the members of insurgent and counterinsurgent groups. For the case of the AUC, the sample is close to representative, since the AUC participated in a collective process where all its members were called to demobilize. For the case of the insurgent groups, the situation is different. The demobilized insurgents left their groups individually risking to be killed as traitors. They may thus be systematically different from the current members of the FARC and the ELN. However, it is not clear how this systematic difference relates to some of our main hypotheses, since we focus on reasons for joining and not for leaving the groups.

\footnotetext{
${ }^{10}$ Numbers in this section are according to information provided by the Colombian Reintegration Agency (ACR).
} 
For example, it is common to hear from deserters that they made their decision because their group betrayed its communist ideals (Anaya 2007). This might speak to a heightened ideological affinity. However, it is also plausible to believe that nonideologized recruits are less attached to their groups and thus more prone to leave. Similarly, with respect to forcible recruitment, two different mechanisms are worth considering. On the one hand, those who choose recruitment, when faced with a potentially life-threatening recruitment "offer," may also choose staying in the group, when leaving implies a similarly life-threatening situation. On the other hand, forcible recruits might be particularly resentful and thus more prone to abandon their group than would other insurgents. In sum, available data are insufficient to address the selection problems, especially for insurgents. However, since this study systematically adds findings to earlier results, the inherent biases are less limiting. We delineate the various selection biases below in order to frame the subsequent discussion of our findings.

Most research on individual level determinants for joining armed groups relies on some type of retrospective data, to which several sources of bias apply (see also Kalyvas 2006, 100). Generally speaking, ex-combatants are a difficult population to interview: fear of discrimination, a desire to avoid public appearance, and anxiety due to security threats may reduce willingness to participate in academic investigations. The enumeration process of this survey was designed to mitigate ex-combatants' concerns. Other sources of bias relate to cognitive dissonance and narrative remembrance of past experiences (White 2007). In accordance with these potential biases, we might say that the question we really ask in a survey questionnaire is: "Which of the following options for joining an armed group is most consonant with the personal narrative view you hold of yourself today?" The answer to this question is not necessarily related to what we are 
really interested in, namely the reasons for joining back then, but rather to the current narrative self-construction of the respondent.

Retrospective surveys and other types of interview methods are still useful for finding answers to our original research question, in at least three ways. First, even if retrospective answers are highly biased, they may still be indicators of a lived experience. Among all the options a person has for narrative reconstruction, we believe the actual past is the most probable option to be chosen. Second, retrospective answers might have an important value for today. Ex-combatants are our preferred interview partners for identifying reasons for joining armed groups. What is important for them today might be crucial knowledge for reintegration and reconciliation efforts in postconflict societies. Ex-combatants who say that they entered an armed group because of ideology might behave differently in the present than people who say they entered for money (Nussio 2012), offering insight into policy design and implementation discussions. Third, we have to differentiate between more or less narrative-prone indicators. Although we cannot say that with any precision, it seems intuitive that a person reporting the material of the walls in a house he lived some years ago (an indicator of grievance) will be less prone to lie, unconsciously distort reality, or not remember things correctly, than a person asked if he joined the armed group out of ideological reasons (see also Gutiérrez Sanín 2008; Kalyvas 2006). We consider these potential sources of bias further in the next section.

Observations in the RD come from 846 former AUC members, 472 ex-Farc, 119 ex-ELN, and 36 demobilized individuals who were members of smaller guerrilla groups. About 15 per cent from them are women. They each were interviewed for about two hours about their experiences before, during, and after being part of an armed 
group. No previous data collection effort has covered such a wide range of topics, which allows for the testing of a series of theories.

\section{Empirical results and discussion}

Our analytical strategy is composed of four moments: first, we identify all relevant available indicators in the Reference Database for each dimension in each of the five main theories. Second, we perform a preliminary bivariate analysis, to identify which ones are the most relevant to distinguish factions (this information will be provided in an Online Appendix). Third, we analyze the selected indicators to see whether they can be considered to be valid measures of a common latent variable. Here we rely on the use of principal components analysis as data reduction tool (Online Appendix). Fourth, we perform a regression analysis including all relevant variables to identify the most robust indicators of differentiation (see Table 2). ${ }^{11}$ As the dependent variable in the regression analysis, we will use one indicator: first group joined $(0=$ AUC, $1=$ FARC, ELN $)$. The last column in the regression table shows odds ratios. Ratios below 1 indicate a higher likelihood of being a counterinsurgent and odds ratios above 1 a higher likelihood of being an insurgent.

At first glance, indicators from all five theories and demographics support our main hypothesis: Combatants from insurgencies and counterinsurgent groups report different demographics, grievances, response to incentives, community networks, desires, and experiences with coercion prior to joining their respective groups. Also, a large series of findings from earlier studies receive additional support in our analysis of differentiating factors.

\footnotetext{
11 We present only the most demanding model including all variables since prior studies have already looked at partial specifications of these variables and our intention is to identify additional supporting evidence for earlier findings.
} 


\section{Table 2: MLE regression model for faction}

Coefficient $\quad$ S.E. p-value $95 \%$ Confidence Interval Odds Ratio

\begin{tabular}{|c|c|c|c|c|c|c|}
\hline $\begin{array}{l}\text { Demographics } \\
\text { gender }\end{array}$ & -0.729 & 0.313 & 0.020 & -1.343 & -0.116 & 0.482 \\
\hline age & -0.033 & 0.017 & 0.053 & -0.067 & 0.0004 & 0.967 \\
\hline age at recruitment & -0.026 & 0.086 & 0.766 & -0.195 & 0.143 & 0.975 \\
\hline rural origin & 0.218 & 0.238 & 0.359 & -0.248 & 0.684 & 1.244 \\
\hline \multicolumn{7}{|l|}{ Grievances } \\
\hline material needs & 0.402 & 0.115 & 0.000 & 0.176 & 0.627 & 1.494 \\
\hline ideology & 0.608 & 0.135 & 0.000 & 0.344 & 0.873 & 1.837 \\
\hline food & -0.126 & 0.247 & 0.611 & -0.610 & 0.358 & 0.882 \\
\hline economy & -0.003 & 0.217 & 0.988 & -0.428 & 0.422 & 0.997 \\
\hline \multicolumn{7}{|l|}{ Selective incentives } \\
\hline material incentives & -0.785 & 0.130 & 0.000 & -1.041 & -0.529 & 0.456 \\
\hline protection offer & -0.071 & 0.379 & 0.852 & -0.814 & 0.673 & 0.932 \\
\hline \multicolumn{5}{|l|}{ Community networks } & 1.546 & 2.521 \\
\hline guerrilla presence & 1.698 & 0.364 & 0.000 & 0.985 & 2.411 & 5.462 \\
\hline paramilitary presence & -1.706 & 0.235 & 0.000 & -2.166 & -1.246 & 0.181 \\
\hline family politics & -0.239 & 0.107 & 0.026 & -0.448 & -0.029 & 0.788 \\
\hline family contact & 0.071 & 0.146 & 0.627 & -0.216 & 0.358 & 1.074 \\
\hline weapon & 0.303 & 0.249 & 0.223 & -0.185 & 0.791 & 1.354 \\
\hline family reason & 1.369 & 0.729 & 0.060 & -0.060 & 2.799 & 3.933 \\
\hline $\begin{array}{l}\text { Private desires } \\
\text { draft }\end{array}$ & -0.799 & 0.240 & 0.001 & -1.269 & -0.329 & 0.449 \\
\hline age weapons & -0.055 & 0.023 & 0.016 & -0.099 & -0.010 & 0.947 \\
\hline contact own & -0.587 & 0.409 & 0.152 & -1.390 & 0.215 & 0.556 \\
\hline risk & -0.037 & 0.269 & 0.890 & -0.564 & 0.489 & 0.963 \\
\hline $\begin{array}{l}\text { Coercion } \\
\text { coercion }\end{array}$ & 0.257 & 0.111 & 0.021 & 0.039 & 0.474 & 1.293 \\
\hline constant & 2.417 & 0.773 & 0.002 & 0.902 & 3.9315 & \\
\hline
\end{tabular}

With respect to networks, the indicators most suitable for explaining differences are those related to territorial presence, which display the largest coefficients of all indicators and high levels of significance (odds ratios: 0.18 for paramilitary presence and 5.46 for guerrilla presence). In descriptive terms, in the case of paramilitaries 84 per cent said that paramilitaries were active in their area the year before joining the group (38 per cent said guerrilla groups were present in their region). In the case of 
former guerrilla members 97 per cent said that guerilla groups were active (66 per cent stated that paramilitaries were in their area). Although territorial presence-as all indicators used for our analysis - is self-reported, it captures territorial presence in a more fine-grained and accurate manner than most standard indicators based on violent presence and reported on aggregate levels of analysis. Territorial presence as differentiating factor is thus a strong finding from this study. However, territorial presence does not necessarily determine the choices of would-be recruits. We believe that the difference is mostly generated in zones of dominance of each group where people have often no other choice than to collaborate with hegemonic actors and where they may gradually slip into their ranks (see Kalyvas 2006). In environments with a more equal presence of both actors, other factors might be decisive for their choice. ${ }^{12}$

Two additional indicators related to community network theories show interesting tendencies. In the case of former guerrilla fighters, it is much more common that they were directly approached by the group (group show) and that they joined because some of their family members or close friends were already in the group (family reason - the coefficient is large but not significant). These results might relate to the fact that guerrilla groups tend to have a long-standing and close relationship to their communities, which allows for more direct contact than in the case of paramilitaries. These results are consistent with theories about peer pressure, primary group cohesion and direct contacts outlined in the literature review.

Confirmatory findings on age at recruitment ${ }^{13}$, gender and coercion reveal significant distinctions between insurgent and counterinsurgent enlistment. On average,

\footnotetext{
12 In the case of guerrilla fighters, about two thirds state that both groups were active in their area of residence before joining. In the case of paramilitaries, about one third stated that both groups were active in their area of residence.

13 Age at recruitment is highly correlated with age of first use of weapons (Pearson's correlation: 0.6). Models that use just one of the two show highly significant results for both with the same direction: the younger, the higher the likelihood of being an insurgent.
} 
paramilitaries joined with 23 years of age (range: 7 to 54) and guerrilla fighters with 18 (range: 5 to 54). In terms of gender, among the surveyed paramilitaries are 9 per cent women, among the guerrilla 25 per cent. It is not clear, however, if insurgent women tend to demobilize more often than men, potentially biasing the results, but the proportion coincides largely with earlier estimations. Coercion is another significant differentiating factor: 2 per cent of paramilitaries state that they were forced to join and 7 per cent among the guerrilla. As mentioned earlier, the higher number of forced recruitment among insurgents might be related to the population of former guerrilla fighters from which the sample for this study was drawn-forcibly recruited insurgents might desert more often than otherwise motivated insurgents. This finding thus has to be taken with a grain of salt. Nonetheless, most ex-combatants who joined a non-state group - regardless of which one it was-before reaching 18 years of age do not see themselves as forcibly recruited even though current Colombian legislation stipulates that those who joined as minors are considered to have been so. Based on our findings, paramilitaries and guerrilla fighters in Colombia are demographically different and might also be different in terms of forcible recruitment. However, these differences might be related to different recruitment strategies and community dynamics in two different ways. First, the factions recruit from specific communities, which results in group compositions that mirror that of the community within which they are embedded. Second, guerrilla groups' closer relationship to specific communities, and its careful knitting of collaboration networks there might open up more possibilities for women, children, and relatives' integration into the faction, which would partially explain the younger age of recruitment among guerrilla fighters and the participation of more women. 
Differences among guerrilla and paramilitary fighters can also be identified in the private desires theories. All of the indicators capturing such elements like lure of weapons, status-seeking and interest in a military life are associated rather with paramilitaries than insurgents expressed in odds ratios below 1, although only one is clearly significant ${ }^{14}$. Ex-paramilitaries were more often interested in joining the armed forces before they joined their group than former guerrilla fighters (paramilitaries 79 per cent, insurgents 58 per cent). ${ }^{15}$ However, the high percentage even for former guerrilla fighters suggests that military life was a widespread desire on both sides. We could deduce that it might have been more important for the surveyed ex-combatants to have any kind of military life than to choose on which side. Factors related to territorial presence and contacts might have turned the balance to one side, rather than a clear preference for either one of the military actors in conflict.

Up to now, although important differences have been established, the mentioned indicators might be compatible with the assertion that combatants from antagonistic groups are actually the same people, but they happened to live in territories dominated by different actors which rely on different recruitment strategies. However, there is a series of other findings that contradicts this assertion and points to differences that are more deeply rooted in pre-enlistment conditions.

The greed-related indicator of material incentives is much more often present among paramilitaries than among guerrilla fighters (odds ratio: 0.46), coinciding with the frequently expressed view of greedy paramilitaries. Paramilitaries have more often been lured by monetary offerings than guerrilla fighters. Grievance indicators on the other hand, are much more important for former guerrilla fighters. Not only were they more appealed by ideological reasons for joining (paramilitaries 2 per cent, insurgents

\footnotetext{
${ }^{14}$ We do not discuss age of first use of weapons due to its high correlation with age at recruitment. 15 Among paramilitaries, 34 per cent became actual members of the armed forces before joining the nonstate armed group, among insurgents 7 per cent.
} 
14 per cent; odds ratio: 1.84 - an indicator that might be affected by narrative reconstruction), but also were they living in much poorer conditions of material needs (odds ratio: 1.46), indicating a socio-economic position in society that grievancetheorists associate with a higher likelihood for rebellion. Given that two very distinct indicators of grievances are significant differentiating factors increases the validity of this finding. Hence, we argue that guerrilla fighters were indeed more grievance-driven and less greedy than paramilitaries before they joined their group. According to these results, a person who actually joined the paramilitaries would have less likely been attracted by the guerrilla recruitment strategy and vice versa.

Other indicators capturing education, rural background, security dilemmas, and the willingness to take risk, do not display significant differences between members of armed groups. However, this does not necessarily mean that these factors are unimportant since in the context of other studies, they have proven to be of some explanatory value. More broadly speaking, in an effort to integrate and validate findings of earlier studies, this article is confirmation-oriented. From this point of view, nonsignificant results are less relevant for the discussion.

\section{Conclusions}

Combatants from insurgent and counterinsurgent groups in Colombia display important differences independent from their socialization processes within their groups or the reintegration processes after their demobilization. Some of these differences are associated with community conditions and recruitment strategies of each of the armed group. We argue that non-state armed groups are located in specific areas and come to dominate certain regions because of a configuration of predominant underlying socioeconomic and political conditions that can be strategically exploited by these groups. 
However, we were not able to assess this hypothesis in the present study. Rather, we were interested in finding out if combatants from insurgent and counterinsurgent groups are systematically different at the individual level with respect to pre-enlistment motivational traits — and indeed they are.

The clearest differences are related to material incentives and grievances which make would-be recruits more receptive for one or another group. Furthermore, we argue that these characteristics, measured through a series of more or less reliable indicators about the past (more reliable: monetary offerings, material needs; less reliable: ideological affinity), were present since before they joined the respective armed groups. They are not simply the result of socialization processes within the group or nostalgic memories after demobilization, both of which might affect retrospective survey data. As important as outlining differences, we identified similarities that prove to be just as relevant. Particularly, the allure for a military life is important for a large share of both would-be guerrillas and paramilitaries. This is a powerful factor to explain why a person joins any armed group when faced with favorable conditions to do so (e.g. territorial presence of armed actors, unemployment etc.).

Pulling our findings together, we propose a configurational logic to make sense of the different explanatory factors. While territorial presence of armed actors confronts people with a potential question of whether to join or not to join an armed group, military allure might push the balance towards joining. However, these factors do not account for their decision to join either one of the sides. In a context in which insurgents and counterinsurgents are present in one and the same area, potential recruits may base their decision of whether to join a guerrilla or paramilitary group on personally held greed and grievances that are embodied more clearly by one or the other side. This understanding implies that any public policy for recruitment prevention should address 
not only material conditions, but also psychological and cultural traits that could trigger individual decisions.

However, we are aware that the presented results are not the last word on differentiating factors for insurgents and counterinsurgents in Colombia and naturally, similar constellations of non-state actors in other contexts might display other motivational differences. Also, even integrating earlier findings using different methodological and theoretical approaches, data generation problems persist and affect the reliability of our inferences. For the case of self-reported retrospective data as used in this study, critical reflection about the reliability of each indicator is one way to increase the transparency of the findings.

For future research on war motivations, self-reported data might still provide suitable indicators. However, more refined sampling strategies and the construction of matched samples of joiners and non-joiners might be particularly useful (see Humphreys and Weinstein 2008). Also, the analysis of competitive conflict environments where would-be recruits interested in a military life can really choose between two or more non-state actors might be revealing for the understanding of war motivations. A rather qualitative process or pathway-oriented approach (see Bosi 2012; Jonsson Forthcoming) may be promising to identify the exact role of family members in the recruitment phase, an element that is particularly relevant in traditional societies where strong ties to family members and distrust towards strangers are frequent.

As stated earlier, narrative reconstruction is a key element for the understanding of self-reported data. An alternative way to make use of data that was clearly affected by such a process, is to look at it from today's perspective of reintegrating excombatants. What does it mean for reconciliation when insurgents say they joined for ideological reasons? What does it mean when former child soldiers do not see their own 
recruitment as forcible? Denying their accounts of the past during the post-conflict

scenario will not make them go away (see Nussio 2012). Anticipating consequential

behavioral manifestations may prevent peacebuilding policies from failure.

\section{References}

Adcock, Robert, and David Collier. 2001. "Measurement Validity: A Shared Standard for Qualitative and Quantitative Research.” American Political Science Review 95 (3): 529-546.

Anaya, Liliana. 2007. "Individual Demobilization and Reintegration Process in Colombia: Implementation, Challenges and Former Combatants Perspectives." Intervention 5 (3): 179-190.

Arjona, Ana, and Stathis N. Kalyvas. 2009. "Rebelling Against Rebellion. Comparing Insurgent and Counterinsurgent Recruitment”. Oxford: Centre for Research on Inequality, Human Security and Ethnicity.

_. 2011. "Recruitment into Armed Groups in Colombia: A Survey of Demobilized Fighters." In Understanding Collective Political Violence, edited by Yvan Guichaoua, 143-172. Basingstoke: Palgrave Macmillan.

Beckett, Ian F. W. 2001. Modern Insurgencies and Counter-insurgencies: Guerrillas and Their Opponents Since 1750. London; New York: Routledge.

Berger, Mark T., and Douglas A. Borer. 2009. Long War - Insurgency, Counterinsurgency and Collapsing. London: Routledge.

Berman, Eli, Michael Callen, Joseph H. Felter, and Jacob N. Shapiro. 2011. "Do Working Men Rebel? Insurgency and Unemployment in Afghanistan, Iraq, and the Philippines." Journal of Conflict Resolution 55 (4): $496-528$.

Blattman, Christopher, and Jeannie Annan. 2010. "The Consequences of Child Soldiering." The Review of Economics and Statistics 92 (4): 882-898.

Blattman, Christopher, and Edward Miguel. 2010. "Civil War.” Journal of Economic Literature 48: 3-57.

Boix, Carles. 2008. "Civil Wars and Guerrilla Warfare in the Contemporary World: Toward a Joint Theory of Motivations and Opportunities." In Order, Conflict, and Violence, edited by Stathis N Kalyvas, Ian Shapiro, and Tarek Masoud, 197-218. Cambridge: Cambridge University Press.

Bosi, Lorenzo. 2012. "Explaining Pathways to Armed Activism in the Provisional Irish Republican Army, 1969-1972." Social Science History 36 (3): 347-390.

CNMH. 2013. Basta Ya! Colombia: Memoria de Guerra y Dignidad. Bogotá: Centro Nacional de Memoria Histórica.

Collier, David, Jody LaPorte, and Jason Seawright. 2012. "Putting Typologies to Work Concept Formation, Measurement, and Analytic Rigor.” Political Research Quarterly 65 (1): 217-232.

Collier, David, and James E. Mahon. 1993. "Conceptual Stretching Revisited: Adapting Categories in Comparative Analysis." American Political Science Review 87 (4): 845-855.

Collier, Paul, and Anke Hoeffler. 1998. "On Economic Causes of Civil War." Oxford Economic Papers 50 (4): 563-73.

- 2004. "Greed and Grievance in Civil War." Oxford Economic Papers 56 (4): 563-595.

Cubides, Fernando. 2005. "Narcotráfico y Paramilitarismo: Matrimonio Indisoluble?” In El Poder Paramilitar, edited by Alfredo Rangel, 205-260. Bogotá: Planeta.

Davies, James C. 1962. “Toward a Theory of Revolution.” American Sociological Review 27 (1): 5-19.

DNP. 2010. "Evaluación de Resultados de La Política de Reintegración Social y Económica Para Personas y Grupos Armados Al Margen de La Ley En Colombia”. Bogotá: DNP, Econometría Consultores.

Dube, Oeindrila, and Juan F. Vargas. 2008. "Commodity Price Shocks and Civil Conflict: Evidence from Colombia." Harvard University Center for International Development Graduate Student and Postdoctoral Fellow Working Paper 14. Boston: Harvard University.

Duncan, Gustavo. 2006. Los Señores de La Guerra: De Paramilitares, Mafiosos y Autodefensas En Colombia. Bogotá: Planeta.

Fearon, James D., and David D. Laitin. 2003. "Ethnicity, Insurgency, and Civil War.” American Political Science Review 97 (01): 75-90. 
Ferro, Juan Guillermo, and Graciela Uribe. 2002. El orden de la guerra: las FARC-EP, entre la organización y la política. Bogotá: Pontificia Universidad Javeriana.

Florez-Morris, Mauricio. 2007. "Joining Guerrilla Groups in Colombia: Individual Motivations and Processes for Entering a Violent Organization.” Studies in Conflict \& Terrorism 30 (7): 615-634.

Gates, Scott. 2002. "Recruitment and Allegiance: The Microfoundations of Rebellion." Journal of Conflict Resolution 46 (1): 111-130.

Goodwin, Jeffrey. 2001. No Other Way Out: States and Revolutionary Movements, 1945-1991. Cambridge: Cambridge University Press.

Granada, Soledad, Jorge Restrepo, and Alonso Tobón. 2009. "Neoparamilitarismo En Colombia.” In Guerra y Violencias En Colombia. Herramientas e Interpretaciones, edited by Jorge Restrepo and David Aponte, 467-500. Bogotá: Pontificia Universidad Javeriana.

Grossman, Hershel I. 2002. "Make Us a King"': Anarchy, Predation, and the State." European Journal of Political Economy 18: 31-46.

Gurr, Ted Robert. 1970. Why Men Rebel. Princeton: Princeton University Press.

Gutiérrez Sanín, Francisco. 2008. "Telling the Difference: Guerrillas and Paramilitaries in the Colombian War." Politics \& Society 36 (1): 3-34.

Hart, Peter. 1999. The I.R.A. and Its Enemies: Violence and Community in Cork, 1916-1923. Oxford University Press.

Horton, Lynn. 1999. Peasants In Arms: War \& Peace in the Mountains of Nicaragua, 1979-1994. Athens: Ohio University Press.

Humphreys, Macartan, and Jeremy M. Weinstein. 2008. "Who Fights? The Determinants of Participation in Civil War." American Journal of Political Science 52 (2): 436-455.

Joes, Anthony J. 2006. Resisting Rebellion: The History and Politics of Counterinsurgency. Lexington: University Press of Kentucky.

Jonsson, Michael. Forthcoming. "Comrades in Arms. Motivational Change and Divergence Inside FARC-EP 2002-2010”. Ph.d. dissertation, Uppsala: University of Uppsala.

Justino, Patricia. 2009. "Poverty and Violent Conflict: A Micro-Level Perspective on the Causes and Duration of Warfare." Journal of Peace Research 46 (3): 315-333.

Kalyvas, Stathis N. 2003. "The Ontology of 'Political Violence': Action and Identity in Civil Wars." Perspectives on Politics 1 (3): 475-494. 2006. The Logic of Violence in Civil War. Cambridge: Cambridge University Press.

Kalyvas, Stathis N., and Matthew Adam Kocher. 2007. "How 'Free' Is Free Riding in Civil Wars?: Violence, Insurgency, and the Collective Action Problem." World Politics 59 (2): 177-216.

Keen, David. 2000. "Incentives and Disincentives for Violence." In Greed and Grievance, edited by Mats R. Berdal and David M. Malone, 19-42. Boulder and London: Lynne Rienner Publishers.

Kesby, Mike. 1996. "Arenas for Control, Terrains of Gender Contestation: Guerrilla Struggle and Counter-insurgency Warfare in Zimbabwe 1972-1980.” Journal of Southern African Studies 22 (4): 561-584.

Koc-Menard, Sergio. 2007. "Fragmented Sovereignty: Why Sendero Luminoso Consolidated in Some Regions of Peru but Not in Others." Studies in Conflict \& Terrorism 30 (2): 173-206.

Lichbach, Mark Irving. 1995. The Rebel's Dilemma. Ann Arbor: University of Michigan Press.

Lungo Uclés, Mario. 1996. El Salvador in the Eighties: Counterinsurgency and Revolution. Philadelphia: Temple University Press.

Mason, T. David. 1996. "Insurgency, Counterinsurgency, and the Rational Peasant." Public Choice 86 (12): $63-83$.

Medina, Carlos. 1996. ELN: Una Historia Contada a Dos Veces. Bogotá: Rodrigo Quito Editores. 2008. FARC-EP. Temas y Problemas Nacionales 1958-2008. Bogotá: Universidad Nacional.

Moreno, Florentino, Jaime Carmona, and Felipe Tobón. 2010. "Why Do Girls Join Guerrilla and Paramilitary Groups in Colombia?” Revista Latinoamericana de Psicología 42 (3): 453-467.

Nussio, Enzo. 2011a. "Learning from Shortcomings: The Demobilisation of Paramilitaries in Colombia." Journal of Peacebuilding and Development 6 (2): 88-92.

. 2011b. "How Ex-combatants Talk About Personal Security. Narratives of Former Paramilitaries in Colombia." Conflict, Security \& Development 11 (5): 579-606.

_. 2012. "Emotional Legacies of War Among Former Colombian Paramilitaries." Peace and Conflict: Journal of Peace Psychology 18 (4): 369-383.

Ohlson, Thomas. 2008. "Understanding Causes of War and Peace.” European Journal of International Relations 14 (1): 133-160.

Olson, Mancur. 1965. The Logic of Collective Action: Public Goods and the Theory of Groups. Cambridge: Harvard University Press. 
Paige, Jeffery M. 1975. Agrarian Revolution: Social Movements and Export Agriculture in the Underdeveloped World. New York: Free Press.

Pampinella, Stephen. 2012. "Hegemonic Competition in Intrastate War: The Social Construction of Insurgency and Counterinsurgency in Iraq's al-Anbar Province.” Studies in Conflict \& Terrorism 35 (2): 95-112.

Petersen, Roger D. 2001. Resistance and Rebellion: Lessons from Eastern Europe. Cambridge: Cambridge University Press.

Pinto, María Eugenia, Andrés Vergara, and Yilberto Lahuerta. 2002. "Diagnóstico Del Programa de Reinserción En Colombia: Mecanismos Para Incentivar La Desmovilización Voluntaria Individual". 211. Archivos de Economía. Bogotá: Departamento Nacional de Planeación.

Pizarro Leongómez, Eduardo. 2011. Las Farc (1949-2011): de guerrilla campesina a máquina de guerra. Bogotá: Grupo Editorial Norma.

Regan, Patrick M., and Daniel Norton. 2005. "Greed, Grievance, and Mobilization in Civil Wars." Journal of Conflict Resolution 49 (3): 319-336.

Ribetti, Marcella. 2007. "The Unveiled Motivations of Violence in Intra-State Conflicts: The Colombian Guerrillas." Small Wars \& Insurgencies 18 (4): 699.

—. 2009. "Disengagement and Beyond: Demobilization in Colombia." In Leaving Terrorism Behind: Individual and Collective Disengagement, edited by Tore Bjørgo and John Horgan, 152169. New York: Taylor \& Francis.

Roldán, Mary. 2002. Blood and Fire: La Violencia in Antioquia, Colombia, 1946-1953. Durham: Duke University Press.

Romero, Mauricio. 2003. Paramilitares y Autodefensas, 1982-2003. Bogotá: Planeta.

Scott, James C. 1976. The Moral Economy of the Peasant: Rebellion and Subsistence in Southeast Asia. New Haven: Yale University Press.

Taylor, Michael. 1988. Rationality and Revolution. New York: Cambridge University Press.

Tezcür, Güneş Murat. 2010. "When Democratization Radicalizes: The Kurdish Nationalist Movement in Turkey." Journal of Peace Research 47 (6): 775-789.

Theidon, Kimberly. 2007. "Transitional Subjects: The Disarmament, Demobilization and Reintegration of Former Combatants in Colombia." International Journal of Transitional Justice 1 (1): 66-90.

- 2009. "Reconstructing Masculinities: The Disarmament, Demobilization, and Reintegration of Former Combatants in Colombia." Human Rights Quarterly 31 (1): 1-34.

Theidon, Kimberly, and Paola Andrea Betancourt. 2006. "Transiciones Conflictivas: Combatientes Desmovilizados En Colombia.” Análisis Político 58: 92-111.

Ugarriza, Juan E., and Matthew J. Craig. 2013. "The Relevance of Ideology to Contemporary Armed Conflicts A Quantitative Analysis of Former Combatants in Colombia.” Journal of Conflict Resolution 57 (3): 445-477.

Vadlamannati, Krishna Chaitanya. 2011. "Why Indian Men Rebel? Explaining Armed Rebellion in the Northeastern States of India, 1970-2007.” Journal of Peace Research 48 (5): 605 -619.

Villegas, Cristina. 2009. "Motives for the Enlistment and Demobilization of Illegal Armed Combatants in Colombia." Peace and Conflict: Journal of Peace Psychology 15 (3): 263-280.

Weinstein, Jeremy M. 2007. Inside Rebellion the Politics of Insurgent Violence. Cambridge: Cambridge University Press.

White, Robert W. 2007. "'I'm Not Too Sure What I Told You the Last Time': Methological Notes on Accounts from High-Risk Activists in the Irish Republican Movement." Mobilization 12 (3): $287-$ 305.

Wickham-Crowley, Timothy. 1992. Guerillas and Revolution in Latin America: A Comparative Study of Insurgents and Regimes Since 1956. Princeton: Princeton University Press.

Wittgenstein, Ludwig. 2003. Philosophische Untersuchungen. Fourth edition. Frankfurt: Suhrkamp Verlag.

Wood, Elisabeth Jean. 2003. Insurgent Collective Action and Civil War in El Salvador. Cambridge: Cambridge University Press. 


\section{Appendix: Dimensions and indicators}

\begin{tabular}{|c|c|}
\hline Dimensions $^{16}$ & Reference Database indicators $^{17}$ \\
\hline 1.1 Material needs & $\begin{array}{l}204 \text { reason to drop: Why did you quit school }(1=\text { displacement, could not pay for } \\
\text { school, family needed help, } 0=\text { no choice); } \\
304 \text { a poverty: Main reason for entry }(1=\text { poor, } 0=\text { other choice }) \text {; } \\
305 \text { food: What was offered by the group }(1=\text { food; } 0=\text { other choice }) \\
306 \text { economy: Economy before enrollment }(0=\text { worse, similar; } 1=\text { other choice); } \\
507 \text { walls: Housing wall material before recruitment }(1=\text { unplastered bahareque, } \\
\text { rough wood, bamboo, zinc, without walls; } 0=\text { other choice }) ; \\
508 \text { floor: flooring material }(1=\text { rough wood, cement, earth; } 0=\text { other choice); } \\
509 \text { electricity: house had electricity? (yes }=0, \text { no }=1) ; \\
511 \text { water: housing had aqueduct? }(\text { yes }=0, \text { no }=1) ; \\
512 \text { sewage: housing had sewer? (yes }=0, \text { no }=1) ; \\
513 \text { waste: housing had with garbage collection? }(\text { yes }=0, \text { no }=1) ;\end{array}$ \\
\hline 1.2 Ideological affinity & $\begin{array}{l}\text { 304b ideology reason: Main reason for entry }(1=\text { ideology; } 0=\text { other choice }) \\
305 \text { b colombia What was offered by the group }(1=\text { improve Colombia; } 0=\text { other } \\
\text { choice })\end{array}$ \\
\hline 2.1 Material incentives & $\begin{array}{l}\text { 204b money: Reason I stopped studying }(1=\text { needed to earn money; } 0=\text { other } \\
\text { choice); } \\
\text { 304c income: Main reason for entry }(1=\text { salary, job, } 0=\text { other choice }) \text {; } \\
\text { 305c money offer: What was offered by the group }(1=\text { money, payments, labor, } \\
\text { land, } 0=\text { other choice) }\end{array}$ \\
\hline 2.2 Security dilemma & $\begin{array}{l}\text { 304d protection: Main reason for entry }(1=\text { protection, escape domestic violence; } \\
0=\text { other choice); } \\
\text { 305d protection offer: What was offered by the group }(1=\text { security, } 0=\text { other } \\
\text { choice); } \\
307 \text { security feel: With respect to his life as a civilian, when you joined the first } \\
\text { group you felt: }(1=\text { more secure; } 0=\text { less secure, no difference })\end{array}$ \\
\hline $\begin{array}{l}\text { 3.1 Community } \\
\text { support }\end{array}$ & No relevant indicator found \\
\hline $\begin{array}{l}3.2 \text { Territorial } \\
\text { dominance }\end{array}$ & $\begin{array}{l}\text { 301a group attack: How did you contact the armed group? }(1=\text { group attacked } \\
\text { the town, } 0=\text { other choice); } \\
\text { 301b group show: How did you contact the armed group? }(1=\text { fighters showed } \\
\text { up, } 0=\text { other choice); } \\
\text { 515a guerrilla presence: Was there presence of Farc/Eln in your living area } \\
\text { before you joined? }(1=\text { yes, } 0=\text { no) } \\
\text { 515b paramilitary presence: Was there presence of paramilitaries in your living } \\
\text { area before you joined? }(1=\text { yes, } 0=\text { no) }\end{array}$ \\
\hline 3.3 Family influence & $\begin{array}{l}\text { 201a family politics father: Did your father usually vote? }(1=\text { yes, } 0=\text { no }) \text {; } \\
\text { 201b family politics mother: Did your mother usually vote? }(1=\text { yes, } 0=\text { no); } \\
210 \text { weapon: Person who taught you to use firearms }(1=\text { relative, friend, } 0= \\
\text { other choice); } \\
301 \text { family recruitment: How did you contact the group? }(1=\text { friends and family } \\
\text { joined who before, } 0=\text { other choice }) \text {; } \\
302 \text { family entry: Who did introduce you to the armed group? }(1=\text { relative, } \\
\text { friend, } 0=\text { other choice); } \\
\text { 304e family reason: Main reason for entry }(1=\text { friends and family; }\end{array}$ \\
\hline
\end{tabular}

16 The dimensions and their numbers correspond to the synthesized hypotheses specified above.

17 Original Reference Database indicators were recoded as shown, for a total of 1485 original observations. In each recoding, only response observations are contrasted as zero or 1, dropping out nonresponses. In no case, drop-out rate rises above 4\%, except for reason to drop and reason to drop2 $(7 \%)$. In the case of partner, only 594 participants provided an answer. In the case of guerrilla presence and paramilitary presence, we only contrast observations where respondents chose options FARC, ELN, or AUC. 


\begin{tabular}{|c|c|}
\hline & $\begin{array}{l}\text { love/friendship, } 0=\text { other choice); } \\
518 \text { partner: Was your partner member or collaborator with the armed group? }(1 \\
=\text { yes, } 0=\text { no) }\end{array}$ \\
\hline 4.1 Revenge & $\begin{array}{l}304 \mathrm{f} \text { vengeance: Main reason for entry }(1=\text { revenge, } 0=\text { other choice }) ; \\
305 \text { e vengeance offer; What was offered by the group }(1=\text { revenge, } 0=\text { other } \\
\text { choice) }\end{array}$ \\
\hline 4.2 Military allure & $\begin{array}{l}208 \text { draft: Did you want to serve in the military?; }(\text { yes }=0, \text { no }=1) \text {; } \\
209 \text { age weapons: Age when first used firearms; } \\
\text { 301d contact own: How did you contact the armed group? }(1=\text { sought them } \\
\text { yourself, were founding member, } 0=\text { other choice); } \\
\text { 302b contact none: Who did introduce you to the armed group? }(1=\text { none, } 0= \\
\text { other choice); } \\
\text { 304g risk: Main reason for entry ( } 1=\text { power, adventure, like weapons, army } \\
\text { rejected, } 0=\text { other choice; } \\
\text { 305f access: What was offered by the group }(1=\text { mating females/males, status, } \\
\text { reputation, } 0=\text { no choice) }\end{array}$ \\
\hline 5.1 Coercion & $\begin{array}{l}\text { 301e forced contact: How did you contact the armed group? }(1=\text { by force; } 0=\text { no } \\
\text { choice); } \\
\text { 304h force: Main reason for entry }(1=\text { by force; } 0=\text { other choice })\end{array}$ \\
\hline 6. Demographics & $\begin{array}{l}102 \text { age: age in years; } p 520 \text { antes: age of recruitment; } 103 \text { rural: type of birthplace } \\
\text { ( } 0=\text { urban, } 1=\text { =rural); } 101 \text { gender: }(0=\text { female, } 1=\text { male }) .\end{array}$ \\
\hline
\end{tabular}

